\title{
Latest Permian Entactinaria (Radiolaria) from southern Guangxi, China
}

\author{
QINGLAI FENG, SONGZHU GU, WEIHONG HE \& YUXI JIN \\ Faculty of Earth Sciences, China University of Geosciences, Wuhan 430074, China (e-mail: qinglaifeng@cug.edu.cn)
}

\begin{abstract}
A highly diverse and well-preserved latest Permian radiolarian fauna was obtained from muddy siliceous rocks and siliceous mudstones of the Dalong Formation, southern Guangxi, China. Specimens of the Order Entactinaria were selected for taxonomic study. Thirty-four species, among which were nine new species and twelve unidentified species, are included in this investigation. The nine new species are Entactinia wangi, Entactinia minuta, Entactinia sashidai, Trilonche textiles, Triaenosphaera variabilis, Triaenosphaera megacantha, Provisocyntra densa, Provisocyntra ormistoni and Wuyia dongpanica. Permian species of the Family Spongentactiniidae Nazarov are reported first and the extinction pattern of the Order Entactinaria is discussed. J. Micropalaeontol. 26(1): 19-37, April 2007.
\end{abstract}

KEYWORDS: radiolaria, latest Permian, taxonomy, evolution, South China

\section{INTRODUCTION}

The radiolarian Order Entactinaria was proposed originally by Kozur \& Möstler (1982) and is characterized by an initial spicule located inside a spherical shell or the innermost concentric shell (Dumitrica in De Wever et al., 2001). Members of the order were common in the Palaeozoic and Triassic, and became less common in the Jurassic, Cretaceous and Cenozoic. Systematic palaeontological study of Palaeozoic Entactinaria began with the classical works of Foreman (1963), Deflandre (1973), Nazarov (1975), Holdsworth (1977) and Kozur \& Möstler (1982). During the 1980s, systematic taxonomy investigations on the order were conducted in Europe, Asia, North America and Australia. Won (1983) and Gourmelon (1987) investigated many well-preserved Early Carboniferous Entactinaria from Germany and France, respectively. Nazarov \& Ormiston $(1983,1985)$ described Late Palaeozoic Entactinaria from West Australia, Southern Urals and West Texas. Sashida \& Tonishi $(1985,1988)$ contributed to the detailed taxonomic studies on Late Permian Entactinaria from central Japan. Kozur \& Möstler (1989) reported well-preserved Permian Entactinaria from the Cis-Ural. Since the 1990s, many taxonomic papers covering the order have been published, including Germany (Braun, 1990), Italy (Kozur, 1993), USA (Blome \& Reed, 1992), Russia (Afanasieva, 2000), China (Wang et al., 1994; Wu et al., 1994; Feng et al., 1998; Yao \& Kuwahara, 1999, 2000), Thailand and Malaysia (Sashida et al., 1995; 2000b) and Australia (Aitchison, 1993). However, the taxonomy of Late Permian Entactinaria is still poorly understood, partly because of the rarity of these radiolarians and partly due to the lack of well-preserved radiolarians revealing inner structures necessary for taxonomic study.

Recently, a well-preserved latest Permian radiolarian fauna was recovered from muddy siliceous rocks and siliceous mudstones of the Dalong Formation, southern Guangxi, China (Fig. 1). Primarily 138 species, belonging to Albaillellaria, Entactinaria, Spumellaria and Latentifistularia, were identified. Among them, 34 species of the Order Entactinaria are illustrated and described in this paper (Fig. 2).

\section{STRATIGRAPHY AND RADIOLARIAN LOCALITY}

The studied area is located between Dongmen and Liuqiao Towns, Fusui County, Guangxi Zhuang Autonomous Region in southern China (Fig. 1) and the strata distributed in this region mainly consist of Late Permian and Early Triassic sections (BGMRG, 2001). The Late Permian is divided into three formations in ascending order: the Heshan, Changxing and Dalong (Fig. 1). All specimens described in the present paper were collected from the Dalong Formation from the Dongpan Section (which equates to the Liuqiao Section of Shang et al., 2001) near Dongpan Village $\left(22^{\circ} 16.196^{\prime} \mathrm{N}, 107^{\circ} 41.505^{\prime} \mathrm{E}\right)$. In this section, the Dalong Formation overlies the limestones of the Changxing Formation of Early Changhsingian age and is overlain by the mudstones of the Early Triassic Luolou Formation containing Ophiceras tingi Tien and Claraia dieneri Nakazawa. Therefore, stratigraphically the Dalong Formation is Late Changhsingian in age. The lower part of the Dalong Formation is mainly composed of mudstones and siliceous rocks; the middle part, of bedded siliceous rocks with shales; and the upper part, of siliceous mudstones and bentonite with Permian brachiopods and bivalves. Abundant well-preserved radiolarians were obtained from the bedded siliceous rocks and siliceous mudstone of the middle and upper parts, including Neoalbaillella optima Ishiga et al., Albaillella triangularis Ishiga et al., and Albaillella yaoi Kuwahara. These and other radiolarians described in this paper therefore belong to the Late Changhsingian Neoalbaillella optima Zone (Yao et al., 2001).

\section{SYSTEMATIC PALAEONTOLOGY}

All specimens described in this paper are deposited in the Geological Museum of China University of Geosciences, Wuhan, the People's Republic of China.

Order Entactinaria Kozur \& Möstler, 1982

Family Entactiniidae Riedel, 1967

Genus Entactinia Foreman, 1963

Type species. Entactinia herculea Foreman, 1963. 

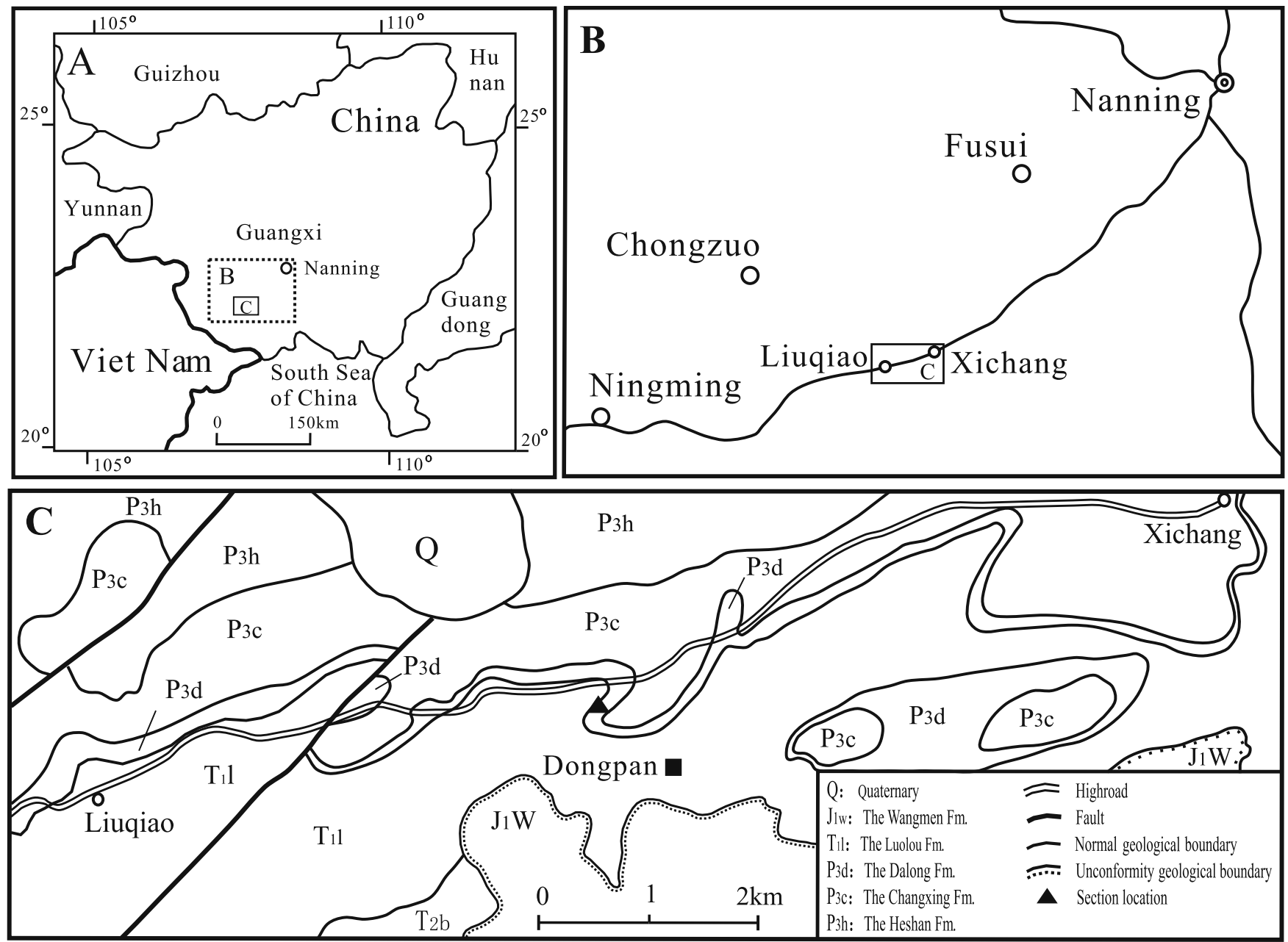

Fig. 1. Geological map and location of the studied area (after BGMRGAR, 2001).

\section{Entactinia itsukaichiensis Sashida \& Tonishi}

(Pl. 1, figs 1-2)

1985 Entactinia itsukaichiensis Sashida \& Tonishi: 9-10, pl. 1, figs $1-10$.

1990 Entactinia itsukaichiensis Sashida \& Tonishi; Ishiga: pl. 1, fig. 1.

1992 Entactinia itsukaichiensis Sashida \& Tonishi; Blome \& Reed: 369, figs 11.2-11.5.

1993 Stigmosphaerostylus itsukaichiensis (Sashida \& Tonishi); Kozur: 120, pl. 3, fig. 13.

1998 Entactinia itsukaichiensis Sashida \& Tonishi; Kuwahara \& Yao: pl. 2, fig. 59.

1998 Entactinia itsukaichiensis Sashida \& Tonishi; Feng et al.: 239, figs 3c, 3d.

2000a Entactinia itsukaichiensis Sashida \& Tonishi; Sashida et al: : 797-799, fig. 7.24.

2000b Entactinia itsukaichiensis Sashida \& Tonishi; Sashida et al.: 251, pl. 1, figs 24-26.

Material. Ten specimens examined by SEM, of which two are illustrated.
Distribution. Abundant in the Late Permian, central Japan, USA, Italy, South China and Thailand.

Remarks. Our specimens compare well to Entactinia itsukaichiensis Sashida \& Tonishi in having a small latticed shell with six three-bladed main spines and numerous thorn-like accessory spines.

\section{Entactinia reticulata Sashida \& Tonishi}

(P1. 1, figs 3-4)

1985 Entactinia reticulata Sashida \& Tonishi: 10-11, pl. 2, figs $7-12$.

Material. Nine specimens examined by SEM.

Distribution. Common in the Upper Permian, central Japan and South China.

Remarks. Specimens illustrated compared well with Entactinia reticulata Sashida \& Tonishi from the Late Permian of central 


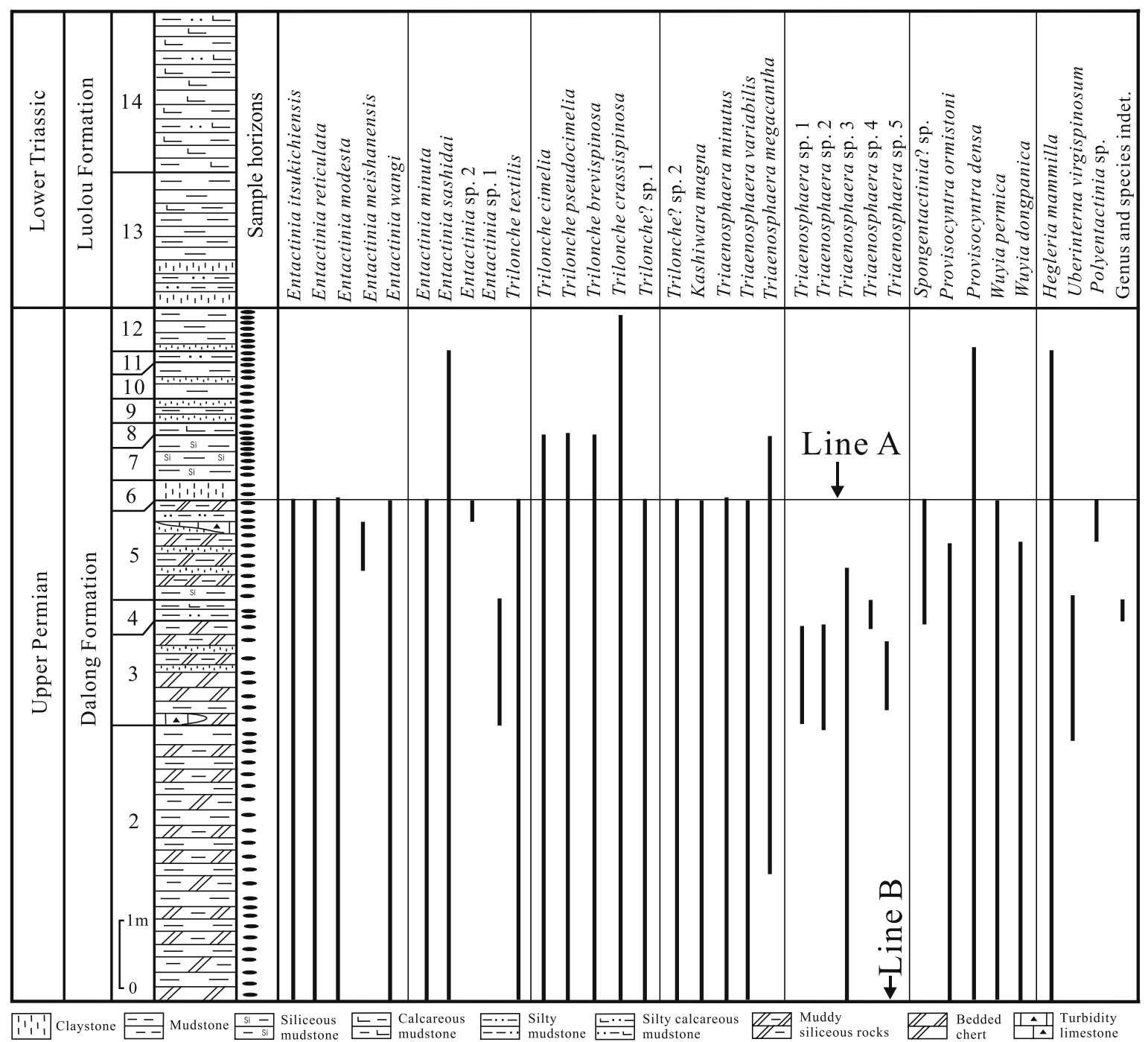

Fig. 2. Distribution of the radiolarians reported in this paper.

Japan in having a very thin shell with large pores and short three-bladed main spines.

\section{Entactinia modesta Sashida \& Tonishi}

(Pl. 1, figs 5-6)

1985 Entactinia modesta Sashida \& Tonishi: 10, pl. 1, figs 11-12; pl. 2, figs 1-6.

Material. Five specimens examined by SEM.

Distribution. Common in the Late Permian, central Japan and South China.

Remarks. Specimens illustrated here compare well with Entactinia modesta Sashida \& Tonishi from the Late Permian of central Japan in having a medium-sized spherical lattice shell with six three-bladed main spines and some small accessory spines.
Entactinia meishanensis $\mathrm{He}$, Feng \& Gu

(Pl. 2, fig. 10)

2005 Entactinia meishanensis He, Feng \& Gu: 210, figs 4.9-4.11.

Material. Two specimens.

Distribution. Rare in the Changhsingian, South China.

Remarks. The specimen illustrated here resembles Entactinia itsukaichiensis Sashida \& Tonishi in the size of test and in the shape of main spines, but differs from it in having more massive, three-bladed accessory spines. It compares well with Entactinia meishanensis $\mathrm{He}$, Feng \& Gu from the Changxing Formation in the Meishan D Section, Changxing, China (He et al., 2005).

Entactinia wangi Feng n. sp.

(Pl. 1, figs 9-20) 


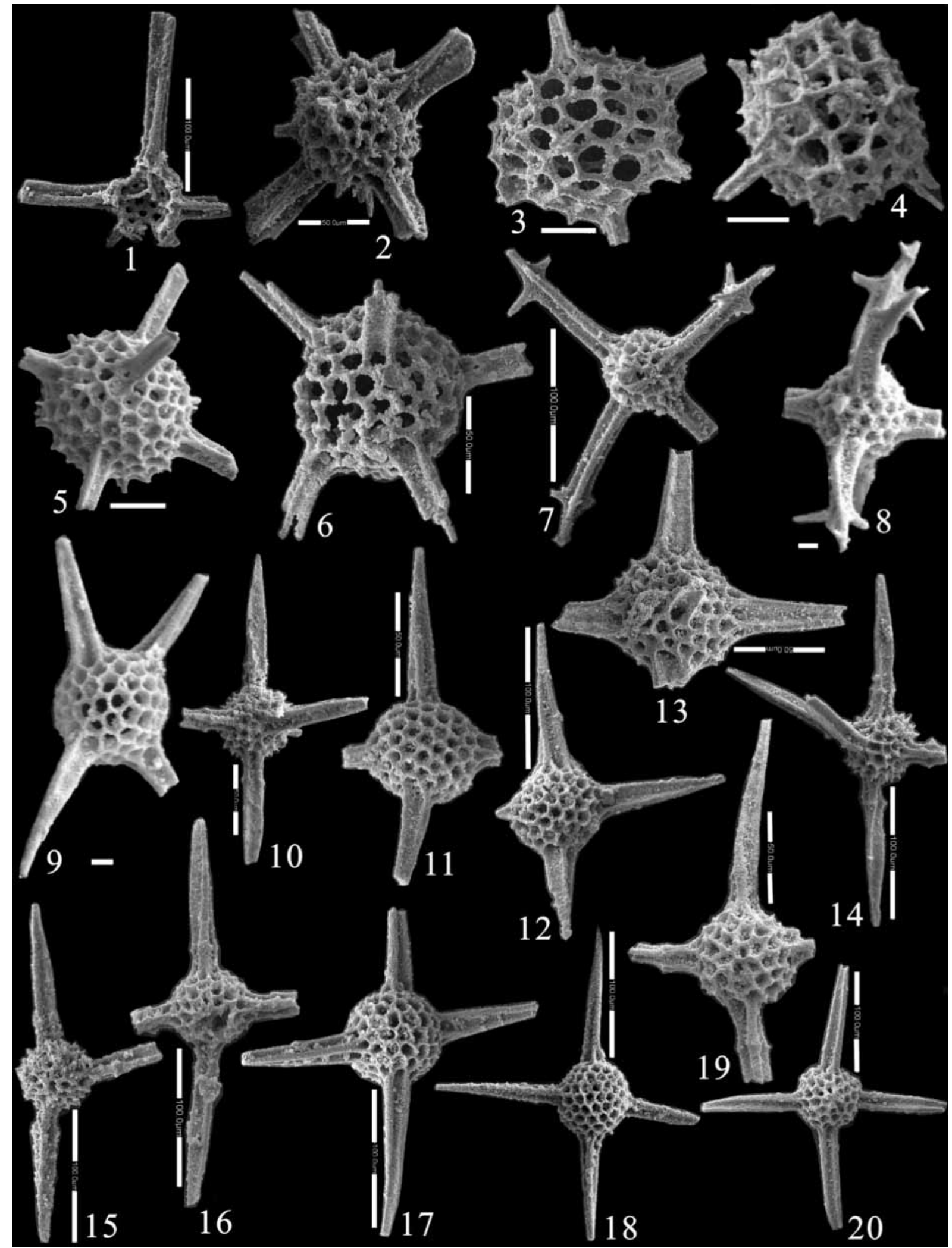


Derivation of name. This species is named in honour of Prof. Wang Yujing, for his studies on Palaeozoic Radiolaria.

Diagnosis. A small spherical latticed shell with four to six long three-bladed main spines.

Holotype. Plate 1 (fig. 9), sample DP4/3404 from the Dalong Formation of the Dongpan section, Fusui County, southern Guangxi, depositional number X0301-37.

Material. Over 40 specimens were found and 23 examined by SEM.

Description. Test is a small, spherical, latticed shell with hexagonal pore frame. Thirty-one to 45 pores visible on the outer surface of hemisphere. Four to six main spines; four co-planar main spines long (1.5-2.5 times of the diameter of the shell), massive, three-bladed, slowly decreasing distally in width; other two main spines similar to the four main spines in length, or shorter, even lacking; the two main spines also three-bladed, and perpendicular with the four co-planar main spines. Accessory spine very short, rod-like.

Dimensions $(\mu \mathrm{m})$. Based on 15 specimens: diameter of shell 56-78; maximum length of long main spines 83-184; maximum width of long main spines 16-22; length of short main spine $0-24$.

Distribution. Abundant in the Late Changhsingian, South China.

Remarks. This new species is similar in outline to Entactinia itsukaichiensis Sashida \& Tonishi, but differs from it in having a smaller shell, shorter main spine, and less accessory spines. It also resembles Lower Carboniferous forms Entactinia parva Won and Entactinia tortispina (Ormiston \& Lane, 1976) in outline, but these two species have longer main spines and accessory spines, and a larger shell.

\section{Entactinia minuta Feng n. sp.}

(Pl. 1, figs 7-8)

Derivation of name. minutus $-a-u m($ Latin, adj. $)=$ small.

Diagnosis. A small spherical latticed test with four to six three-bladed main spines; each main spine has three distal branches.

Holotype. Plate 1 (fig. 8), sample DP4/3408 from the Dalong Formation of the Dongpan section, Fusui County, southern Guangxi, depositional number X0301-38.

Material. Six specimens were found and five specimens examined by SEM.
Description. Test is a small, latticed, spherical shell. Pore frame is small, uniform, pentagonal or hexagonal. Thirty to 35 pores are present on the hemisphere outer surface. Four to six massive, three-bladed main spines similar in size and form; each main spine has three short distal branches. When four main spines are developed on the surface they are co-planar, or tetrahedrally arranged.

Dimensions $(\mu \mathrm{m})$. Based on five specimens: diameter of shell $50-52$; length of longest main spine 70-95; maximum width of long main spine 15-17.

Distribution. Rare in the Late Changhsingian, South China.

Remarks. This new species is similar in outline to Entactinia wangi $\mathrm{n}$. sp., but differs from it in having three distal branches on the end of each main spine. Its spines resemble those of Entactinia pycnoclada Nazarov \& Ormiston, but the latter has a smaller cortical shell. Stigmosphaerostylus sakmaraensis Kozur \& Möstler differs also from this new species in having a larger shell with developed accessory spines and circular to oval pore frames.

\section{Entactinia sashidai Feng n. sp.}

$$
\text { (P1. 2, figs 1-6) }
$$

Derivation of name. This species is named for Dr K. Sashida, in honour of his studies on Palaeozoic Radiolaria.

Diagnosis. Entactinia with a short, conical three-bladed main spine.

Holotype. Plate 2 (fig. 2), sample DP5/2095 from the Dalong Formation of the Dongpan section, Fusui County, southern Guangxi, depositional number X0301-39.

Material. Eleven specimens were examined by SEM.

Description. Test is spherical, latticed, with three to four main spines and numerous accessory spines. Main spines are threebladed, and quickly decrease in width distally; accessory spines are very short, needle-like. Pore frames are hexagonal. Fortytwo to 54 pores present on outer surface of the hemisphere.

Dimensions $(\mu \mathrm{m})$. Based on nine specimens: diameter of outer sphere 91-160; maximum width of external spine 18-35; maximum length of external spine 49-68.

Distribution. Common in the Late Changhsingian, South China.

Remarks. This species is similar to Entactinia modesta Sashida \& Tonishi in outline and size, but differs from it in having shorter, conical three-bladed main spines. It also resembles Entactinia tyrrelli Nazarov \& Ormiston in outline, but the pore frames of the latter are smaller and oval.

Explanation of Plate 1

figs 1-2. Entactinia itsukichiensis Sashida \& Tonishi: 1, DP2/B024; 2, DP4/P016. figs 3-4. Entactinia reticulata Sashida \& Tonishi: 3, DP5/2369; 4, DP3/4548. figs 5-6. Entactinia modesta Sashida \& Tonishi: 5, DP4/3223; 6, DP3/J095. figs 7-8. Entactinia minuta Feng n. sp.: 7, DP2/B016; 8, DP4/3408, holotype. figs 9-20. Entactinia wangi Feng n. sp.: 9, DP4/3404, holotype; 10, DP5/2073; 11, DP3/J098. 12, DP5/2071. 13, DP5/2341. 14, DP3/K052; 15, DP3/J067; 16, DP3/J079; 17, DP4/O057; 18, DP5/1240; 19, DP5/2337; 20, DP5/1167. Scale bar is $10 \mu \mathrm{m}$ in figs 8, 9; 50 $\mu \mathrm{m}$ in figs $2-6$, $10,11,13,19 ; 100 \mu \mathrm{m}$ in figs $1,7,12,14-18,20)$. 


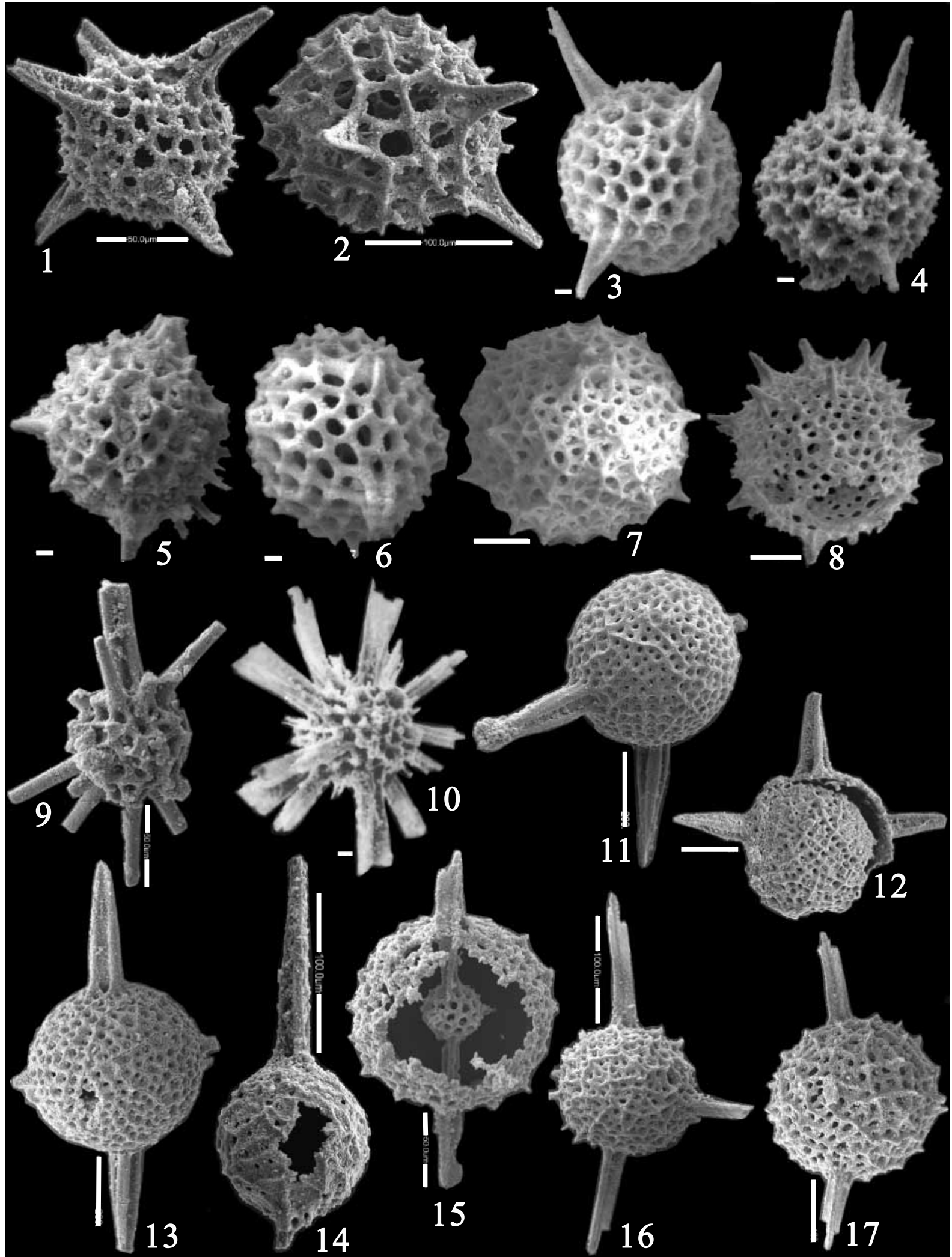


Latest Permian radiolaria, China

\section{Entactinia sp. 1 \\ (Pl. 2, figs 7-8)}

Material. Six specimens found and four examined by SEM.

Description. Single spherical test with short conical spines. Pore frame oval. The cross-section of the spines are three- or fourbladed in its proximal part and circular in its distal part.

Distribution. Rare in the Late Changhsingian, South China.

Remarks. This indeterminate species is similar in outline to Astroentactinia multispinosa (Won, 1983) from the Early Carboniferous, but differs from it in having a single-layered shell with oval pores. It differs from the known species of the genus Entactinia in having numerous, short conical spines.

\section{Entactinia sp. 2}

(Pl. 2, fig. 9)

1998 Entactinia sp. Feng et al.: 240, fig. 3e.

Material. One specimen found and examined by SEM.

Description. Test is small, spherical, and latticed. Pores subcircular, oval. Main spines are three-bladed, massive; accessory spines long, circular in cross-section.

Distribution. Rare in the Late Changhsingian, South and Southwest China.

Remarks. This indeterminate species is similar to Astroentactinia? mirousi Gourmelon, 1986 reported from the Early Carboniferous in outline and size, but differs from it by having more massive three-bladed main spines. It is similar to Entactinia sp. of Feng et al. (1998) from the latest Permian in southwestern Yunnan, Southwest China.

Genus Trilonche Hinde, 1899

Type species. Trilonche vetusta Hinde, 1899.

Trilonche cimelia (Nazarov \& Ormiston)

(Pl. 2, figs 15-17)

1985 Entactinosphaera cimelia Nazarov \& Ormiston: 22, pl. 1, figs. 9, 11.

1991 Entactinosphaera cimelia Nazarov \& Ormiston; Wang: pl. 3, fig. 16.

2001 Entactinosphaera cimelia Nazarov \& Ormiston; Kuwahara \& Yao: pl. 2, fig. 9.

Material. Six specimens examined by SEM, of which three illustrated.

Distribution. Common in the Middle and Late Permian; USA (Texas), Japan, South China.
Remarks. Specimens illustrated here compare well to Trilonche cimelia (Nazarov \& Ormiston) from the Middle Permian of America in having a large outer shell with arcuate ridges and two to three long three-bladed main spines.

Trilonche pseudocimelia (Sashida \& Tonishi)

(Pl. 2, fig. 14)

1988 Entactinosphaera pseudocimelia Sashida \& Tonishi: 528529, figs 7.1-3, 6-8.

Material. Six specimens examined by SEM, of which one is illustrated.

Distribution. Common in the Changhsingian, central Japan and South China.

Remarks. This species is similar to Trilonche cimelia (Nazarov \& Ormiston) in the character of the outer shell, but differs from the latter in having two shorter main spines.

Trilonche brevispinosa (Sashida \& Tonishi)

(Pl. 2, figs 11-13)

1988 Entactinosphaera brevispinosa Sashida \& Tonishi: 529, figs 7.9-13.

Material. Six specimens examined by SEM, of which three are illustrated.

Distribution. Common in the Changhsingian, central Japan and South China.

Remarks. Our specimens differ slightly from Trilonche brevispinosa (Sashida \& Tonishi) from the Late Permian of Japan as some main spines are longer.

Trilonche crassispinosa (Sashida \& Tonishi)

(P1. 3, figs 1-5)

1985 Entactinosphaera? crassispinosa Sashida \& Tonishi: 12, pl. 3 , figs $6-12$.

Material. This species is common in our material. Ten specimens were examined by SEM, of which five are illustrated.

Distribution. Changhsingian, central Japan and South China.

Remarks. Most specimens in our material compare well with Trilonche crassispinosa (Sashida \& Tonishi) from the Late Permian of Japan, but some specimens differ slightly from the latter in having shorter, wider main spines.

Trilonche textilis Feng n. sp.

(Pl. 3, figs 17-20)

Derivation of name. textilis $-i s-e($ Latin, adj. $)=$ woven

Explanation of Plate 2.

figs 1-6. Entactinia sashidai Feng n. sp.: 1, DP2/5767; 2, DP5/2095, holotype; 3, DP3/4579; 4, DP3/4117; 5, DP3/4587; 6, DP3/4532. figs 7-8. Entactinia sp. 1: 7, DP4/3351; 8, DP3/4207. fig. 9. Entactinia sp. 2, DP5/2100. fig. 10. Entactinia meishanensis He, Feng \& Gu, DP5/2591. figs 11-13. Trilonche brevispinosa (Sashida \& Tonishi): 11, DP5/1098; 12, DP2/D040; 13, DP5/2489. fig. 14. Trilonche pseudocimelia (Sashida \& Tonishi), DP2/D023. figs 15-17. Trilonche cimelia (Nazarov \& Ormiston): 15, DP2/5744; 16, DP5/2247; 17, DP5/2353. Scale bar is $10 \mu \mathrm{m}$ in figs $3-8$, 10 ; $50 \mu \mathrm{m}$ in figs $1,9,15,17 ; 100 \mu \mathrm{m}$ in figs $2,11-14,16)$. 


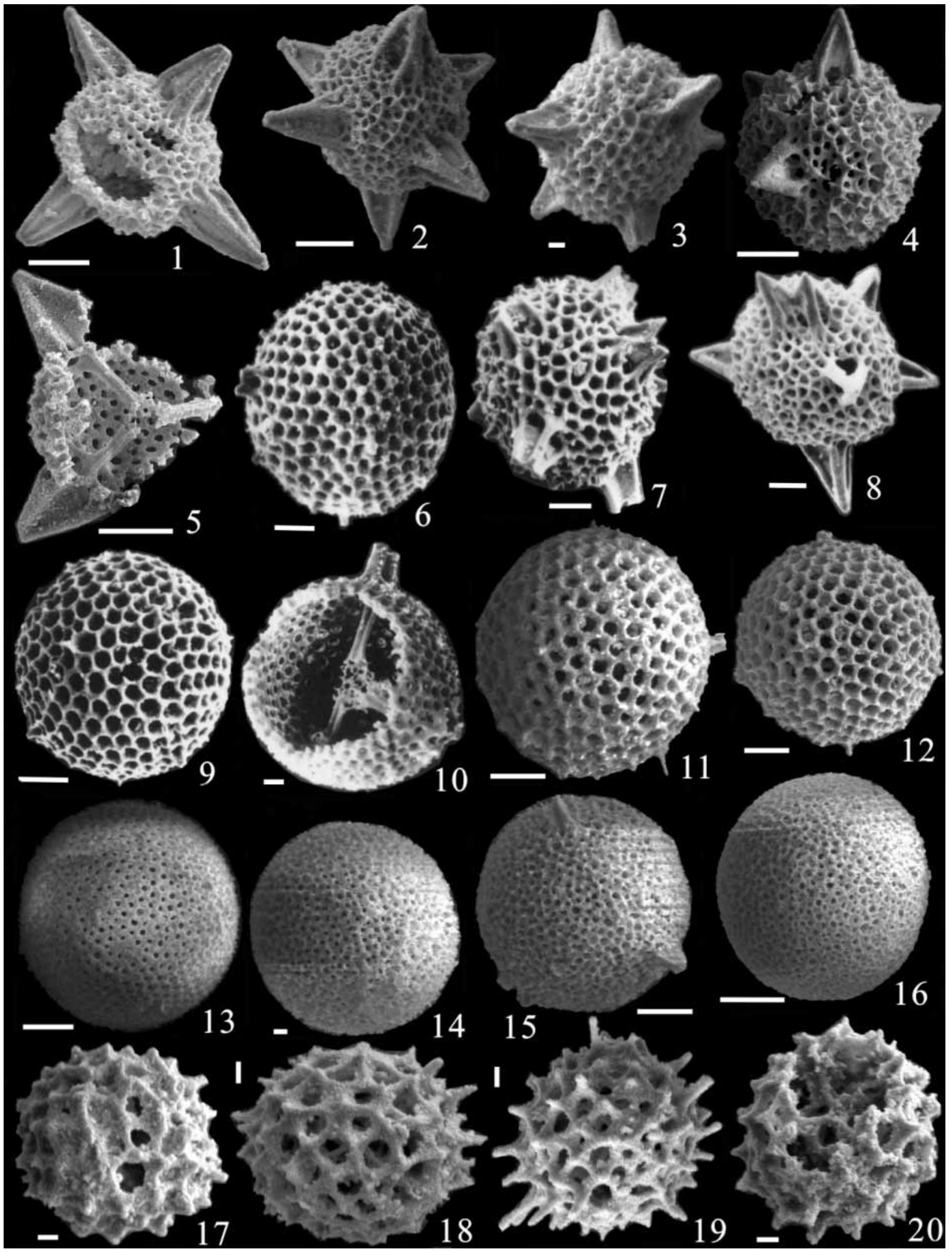

Explanation of Plate 3.

figs 1-5. Trilonche crassispinosa (Sashida \& Tonishi): 1, DP4/3341; 2, DP3/4578; 3, DP3/4431; 4, DP3/4126; 5, DP2/5749. figs 6, 9-12. Kashiwara magna Sashida \& Tonishi: 6, DP5/1592; 9, DP5/1790; 10, DP5/1110; 11, DP3/4220; 12, DP3/4244. figs 7-8. Trilonche? sp. 1: 7, DP5/2297; 8, DP5/2145. figs 13-16. Trilonche? sp. 2: 13, DP3/4238; 14, DP4/3616; 15, DP4/3224; 16, DP4/3248. figs 17-20. Trilonche textilis Feng n. sp.: 17, DP3/4720; 18, DP3/4541, holotype; 19, DP3/4219; 20, DP3/4703. Scale bar $10 \mu \mathrm{m}$ in figs 3, 10, 14, 17-20; 50 $\mu \mathrm{m}$ in figs $1,2,4-9,11-13,15,16$. 
Diagnosis. Small Trilonche with large pores and numerous thorn-like spines at the vertices of the pore frames. Without main spines.

Holotype. Plate 3 (fig. 18), sample DP3/4541 from the Dalong Formation of the Dongpan section, Fusui County, southern Guangxi, depositional number X0301-40.

Material. Sixteen specimens from the Dongpan section examined by SEM, of which four are illustrated.

Description. Test small, spherical, without main spines. Cortical shell with orbicular, elliptical, rounded, polygonal pores that are irregular in size and arrangement. Pore frames tetragonal to hexagonal, and with numerous thorn-like spines at vertices. Thirty-two to 40 pores visible on a hemisphere. Medullary shell large compared with outer shell, subspherical, with large hexagonal pores, and linked with the cortical shell by three-bladed radial bars.

Dimensions $(\mu \mathrm{m})$. Based on eight specimens: diameter of outer sphere 93-105.

Distribution. This species is only known from the latest Changhsingian in southern Guangxi, South China.

Remarks. This new species is distinguished from other species of the genus as it lacks a main spine, and has large pores and numerous thorn-like spines at the vertices of the pore frames.

$$
\begin{aligned}
& \text { Trilonche? sp. } 1 \\
& \text { (Pl. 3, figs 7-8) }
\end{aligned}
$$

Material. Seven specimens all examined by SEM.

Description. Cortical shell large, subspherical, and latticed. Pores are hexagonal, oval. Main spines are short, massive, threeor four-bladed in cross-section, variable in size, more than seven in number, irregularly distributed on the shell. Small accessory spines and nodes arise from junctions of pore frames.

Dimensions $(\boldsymbol{\mu m})$. Based on seven specimens: diameter of outer shell 171-258; length of main spine 62-82; maximum width of main spine $48-71$

Distribution. Common in the Late Permian of South China.

Remarks. The indeterminate species is assigned tentatively to Trilonche Hinde because the inner structure is unknown. Number and irregular arrangement of main spines distinguish this species from other known species of Trilonche.

Trilonche? sp. 2

(Pl. 3, figs 13-16)

Material. Nine specimens examined by SEM.

Description. Test is large, spherical, latticed. Pores are very small, oval. Most specimens lack a main spine; but some have short, three-bladed main spines. The number of the spines varies: from one to six.

Distribution. Common in the Late Permian of South China.

Remarks. This indeterminate species is assigned tentatively to the genus Trilonche Hinde because its inner structure is unknown.

\section{Genus Kashiwara Sashida \& Tonishi, 1985}

Type species. Kashiwara magna Sashida \& Tonishi, 1985.

Distribution. Late Permian, Japan and South China.

Remarks. The genus Kashiwara was proposed by Sashida \& Tonishi (1985) for Kashiwara magna. They thought that this genus was characterized by two spherical lattice shells with four tetrahedrally arranged main spines. On the basis of investigations, this genus consists of a latticed cortical shell and two latticed inner shells. The cortical shell connected with first inner shell by three to four three-bladed beams, and the first inner shell connected with second inner shell by three to four strong three-bladed beams and numerous thin rays. It resembles the genus Uberinterna Sashida \& Tonishi, 1988 in inner structure, but Uberinterna differs from Kashiwara in having six threebladed beams between the cortical shell and the first medullary shell and in having more than two inner shells.

Kashiwara magna Sashida \& Tonishi

(Pl. 3, figs 6, 9-12; Pl. 6, figs 12-20)

1985 Kashiwara magna Sashida \& Tonishi: 15, pl. 5, figs 4-12.

Material. This species is abundant in our material. Twenty-nine specimens were examined by SEM, of which eleven are illustrated.

Distribution. Changhsingian, central Japan and South China.

Remarks. Our specimens differ slightly from Kashiwara magna illustrated by Sashida \& Tonishi (1985) in having thinner main spines and developed secondary spines.

Genus Triaenosphaera Deflandre, 1973 emend. Gourmelon, 1987

Type species. Triaenosphaera sicarius Deflandre, 1973

Triaenosphaera minutus Sashida \& Tonishi

(Pl. 4, figs 6-9)

1988 Triaenosphaera minutus Sashida \& Tonishi: 530, figs 8.18.6 .

Material. This species is common in our material and four specimens are illustrated.

Distribution. Late Permian; Japan and South China. 


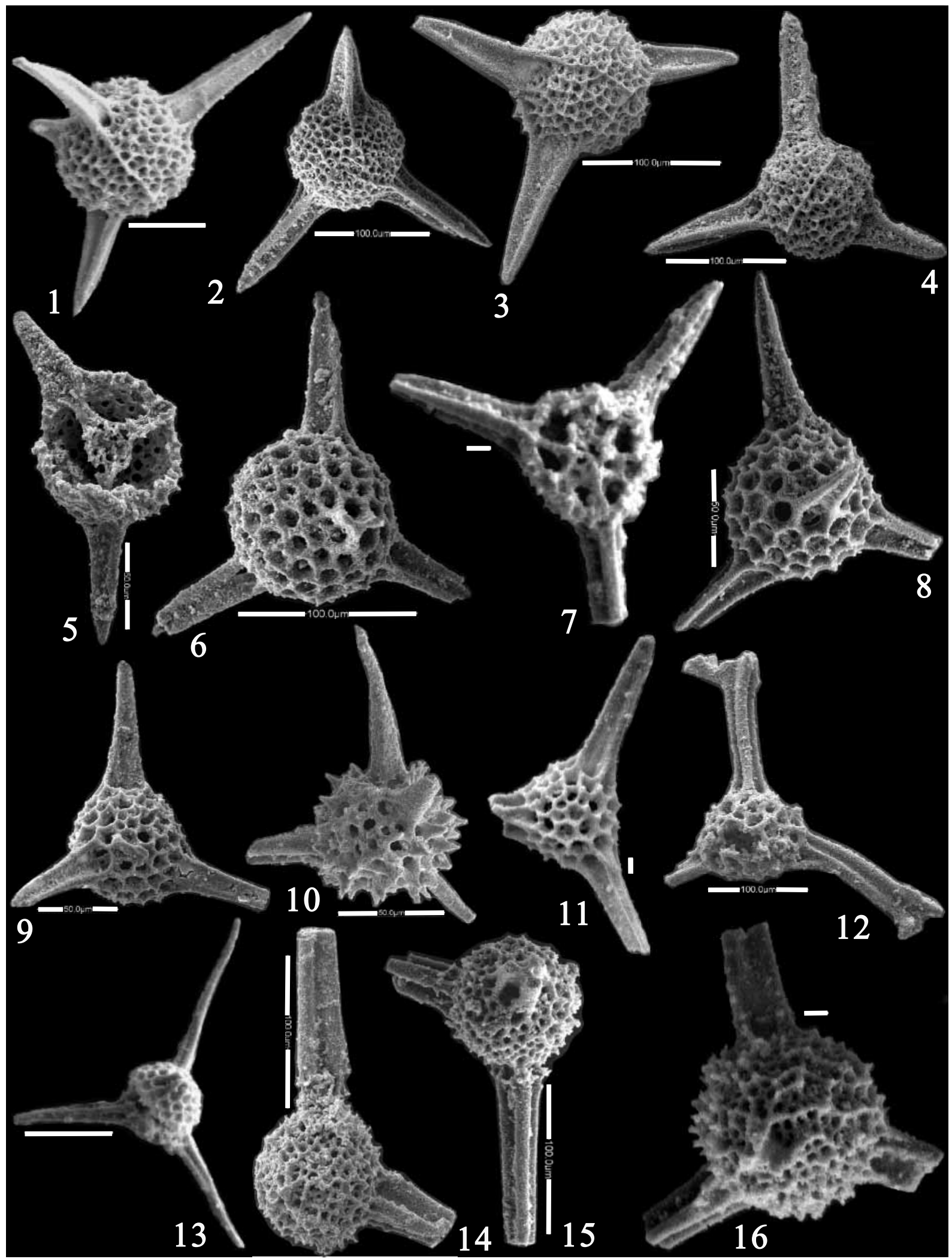


Latest Permian radiolaria, China

Triaenosphaera variabilis Feng n. sp.

(Pl. 4, figs 1-5)

Derivation of name. variabilis $-i s-e($ Latin, adj. $)=$ alterable.

Diagnosis. Triaenosphaera with three co-planar massive main spines and a poorly developed main spine.

Holotype. Plate 4 (fig. 1), sample DP4/3436 from the Dalong Formation of the Dongpan section, Fusui County, southern Guangxi, depositional number X0301-41.

Material. Twenty-one specimens from the Dongpan section were examined by SEM, of which five are illustrated.

Description. Test small, spherical with three to four main spines. Cortical shell comprises small pore frames with poorly developed nodes at vertices and has some narrow ridges. Pore frames usually hexagonal. Sixty-five to 130 pores present on a hemisphere. Medullary shell is small, subspherical, with small pores, and linked with the cortical shell by three-bladed radial bars. These bars extend beyond cortical shell into main spines. Main spines are three-bladed; three massive, usually co-planar, the fourth mostly very short, nearly perpendicular to the three spines.

Dimensions $(\mu \mathrm{m})$. Based on nine specimens: diameter of cortical shell 91-100; maximum width of spines 30-35; maximum length of spines 100-125; diameter of medullary shell 31 .

Distribution. This species is known only from the latest Changhsingian in southern Guangxi, South China.

Remarks. This new species is distinguished from other known species of the genus by the characteristic arrangement of main spines.

Triaenosphaera megacantha Feng n. sp.

(P1. 4, figs 14-16)

Derivation of name. megacanthus (Greek)=large spine.

Diagnosis. Triaenosphaera with four elongate, strong, threebladed spines.

Holotype. Plate 4 (fig. 16), sample DP3/4246 from the Dalong Formation of the Dongpan section, Fusui County, southern Guangxi, depositional number X0301-42.

Material. Six specimens from the Dongpan section examined by SEM, of which three illustrated.
Distribution. This species is known only from the uppermost Changhsingian in southern Guangxi, South China.

Description. Test very small, spherical with four main spines. Cortical shell comprises small pore frames with poorly developed nodes at vertices. Pores small, oval, and dense. The four main spines tetrahedrally disposed, and similar in outline and size. They are three-bladed, massive, long (about two times the diameter of test), and gradually tapering distally.

Dimensions $(\boldsymbol{\mu m})$. Based on five specimens: diameter of cortical shell 82-100; maximum width of main spine 30-35; maximum length of main spine 155 .

Remarks. This new species is distinguished from the other species of the genus by having a smaller shell and four long, massive main spines.

\section{Triaenosphaera $\mathrm{sp} .1$}

(Pl. 4, fig. 11)

Material. Only one specimen was recovered in the present study.

Description. Test small, subtriangular with three main spines. Cortical shell comprises small pore frames with poorly developed nodes at vertices. Pore frames usually hexagonal. Thirtyfive pores visible on a hemisphere. Medullary shell small, subspherical. Main spines three-bladed, massive, co-planar, gradually decreasing in width distally.

Distribution. This indeterminate species is known only from the latest Changhsingian in southern Guangxi, South China.

Remarks. The indeterminate species is similar to Triaenosphaera minutus Sashida \& Tonishi in pore character, but is distinguished from it by having three co-planar, more elongate main spines and smaller cortical shell.

Triaenosphaera sp. 2

(Pl. 4, fig. 13)

Material. Only one specimen was recovered in the present study.

Description. Test small, spherical with four main spines. Cortical shell comprises small, usually hexagonal pore frames. Thirtyseven pores are visible on a hemisphere. The four main spines tetrahedrally arranged. They are similar in outline and size, namely three-bladed, thin, long (about twice the diameter of the test) and gradually decreasing in width distally.

Distribution. This indeterminate species is known only from the latest Changhsingian in southern Guangxi, South China.

Explanation of Plate 4

figs 1-5. Triaenosphaera variabilis Feng $\mathrm{n}$. sp.: 1, DP4/3436, holotype; 2, DP2/A013; 3, DP3/F022; 4, DP4/Q054; 5, DP5/1063. figs 6-9. Triaenosphaera minutus Sashida \& Tonishi: 6, DP2/B033; 7, DP3/4791; 8, DP2/C024; 9, DP2/D024. fig. 10. Triaenosphaera sp. 4, DP4/O004. fig. 11. Triaenosphaera sp. 1, DP3/4218. fig. 12. Triaenosphaera sp. 5, DP3/4218. fig. 13. Triaenosphaera sp. 2, DP3/4218. figs 14-16. Triaenosphaera megacantha Feng n. sp.: 14, DP5/1113; 15, DP5/2312; 16, DP3/4246, holotype. Scale bar is $10 \mu \mathrm{m}$ in figs 7, 11, 16; $50 \mu \mathrm{m}$ in figs $1,5,8-10 ; 100 \mu \mathrm{m}$ in figs $2-4,6,12-15$. 


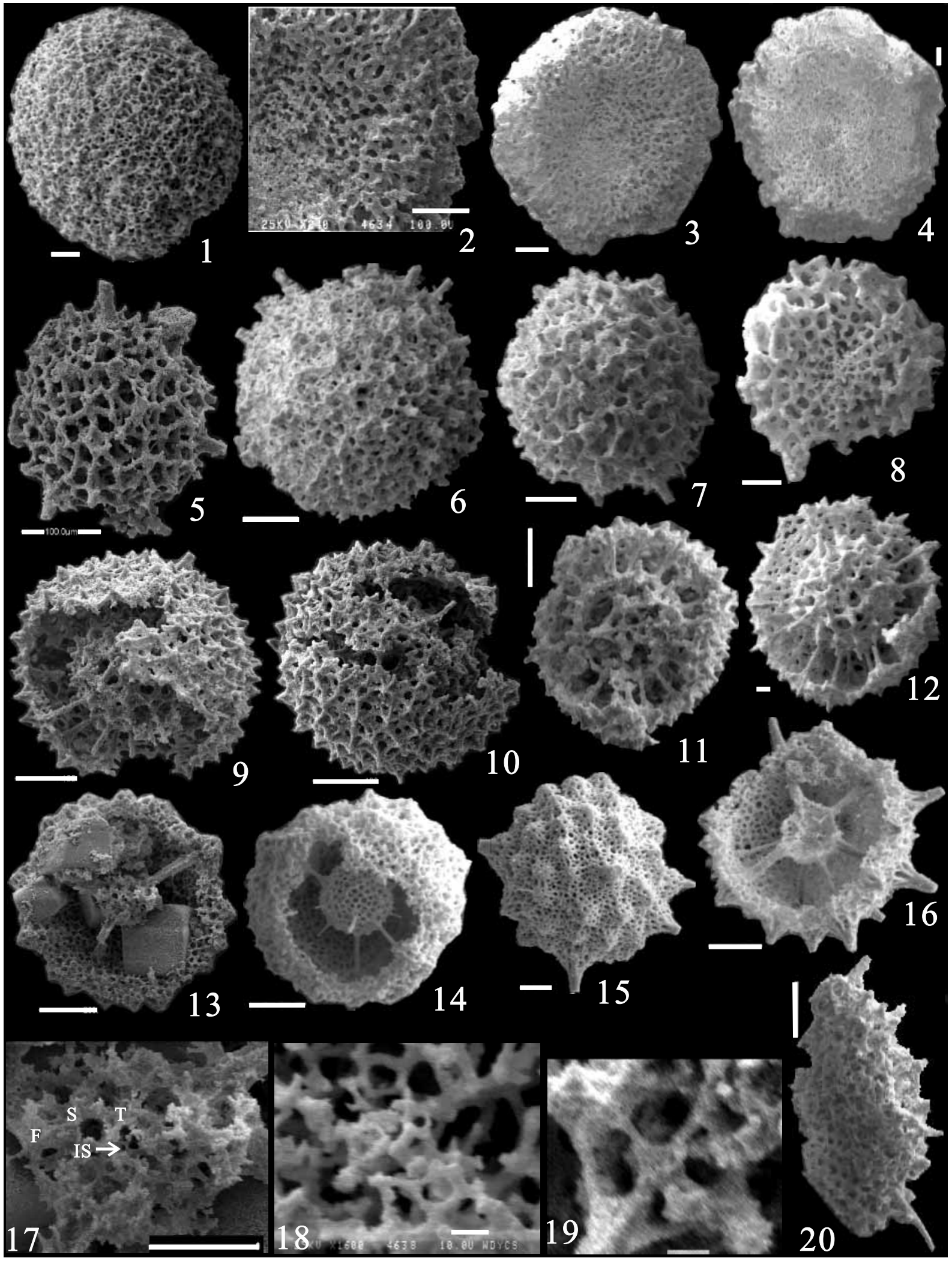


Remarks. The indeterminate species differs from Triaenosphaera megacantha $\mathrm{n}$. sp. in having larger pores and thinner main spines. It resembles Triaenosphaera longispina Sashida (Sashida et al., 2000b) in outline, but the latter has well-developed accessory spines.

\section{Triaenosphaera sp. 3}

(Pl. 6, figs 2-4)

Material. Four specimens were recovered in the present study.

Description. Test small, spherical with four main spines. Cortical shell with large pore frames. Pore frames hexagonal, triangular, or reniform. The four main spines tetrahedrally arranged. They are similar in outline, being three-bladed, but differ in size; usually three are robust and one thin.

Distribution. This species is known only from the latest Changhsingian in southern Guangxi, South China.

Remarks. This species is similar in outline to Triaenosphaera minuta Sashida \& Tonishi, but differs from it in having larger, irregular pores. It differs also from Triaenosphaera variabilis $\mathrm{n}$. sp. in having fewer and larger pores.

\section{Triaenosphaera sp. 4}

(Pl. 4, fig. 10)

Material. Only one specimen was recovered in the present study.

Description. Test small, spherical with four main spines. Cortical shell comprises hexagonal pore frames with conical secondary spines at vertices. Thirty-one pores are visible on a hemisphere. The four main spines tetrahedrally disposed. They are circular or three-bladed in cross-section, gradually decreasing in width distally.

Distribution. This indeterminate species is known only from the latest Changhsingian in southern Guangxi, South China.

Remarks. The indeterminate species is similar to Triaenosphaera minuta Sashida \& Tonishi in outline, but differs from it in having developed secondary spines and rod-like main spines.

\section{Triaenosphaera sp. 5}

(Pl. 4, fig. 12)

Material. Only one specimen was recovered in the present study.

Description. Test small, spherical with four strong main spines. Cortical shell comprises subcircular pore frames. Twenty-eight pores are visible on hemisphere. The main spines three-bladed and have short distal branches.
Distribution. This indeterminate species is known only from the latest Changhsingian in southern Guangxi, South China.

Remarks. Strong main spines with distal branches distinguish this indeterminate species from other known species of this genus.

\section{Wuyia Feng n. gen.}

Type species. Wuyia dongpanica Feng n. gen. \& sp.

Derivation of name. This genus is named in honour of Prof. Wu $\mathrm{Yi}$, for his studies on the stratigraphy of the Guangxi Zhuang Autonomous Region.

Diagnosis. Spherical test composed of three concentric shells and a small microsphere.

Description. Test spherical in outline, composed of three concentric shells and a small microsphere. Cortical and first inner shells are connected by numerous beams, while other inner shells and microsphere are linked by four to six three-bladed beams. Cortical shell is with, or without main spines, but has numerous short spines.

Distribution. Middle and Late Permian. Japan, West Texas and South China.

Remarks. This new genus is similar in its characteristics of the cortical shell to Meschedea Won, 1983, but the innermost shell of Meschedea is quite large. Trilonche Hinde differs from this new genus in having only one inner shell. Late Permian Meschedea permica Sashida \& Tonishi from Japan and Middle Permian Meschedea? endocarpa Nazarov \& Ormiston, 1993 from USA are assigned to this new genus.

Wuyia permica (Sashida \& Tonishi, 1985)

(Pl. 6, figs 9-11)

1985 Meschedea permica Sashida \& Tonishi: 15-16, pl. 4, figs $10-12$; pl. 5, figs $1-3$.

Material. Five specimens examined by SEM.

Distribution. Late Permian, central Japan and South China.

Remarks. Our specimens compare well to Meschedea permica from the Late Permian of central Japan (Sashida \& Tonishi, 1985 ) in the outline of the shell and spine, and in the structure of the cortical shell. This species is assigned to the new genus Wuyia according to its inner structure.

figs 1-4. Provisocyntra densa Feng n. sp.: 1, DP3/4630, holotype; 2, DP3/4634, magnification of fig. 3; 3, DP3/4623; 4, DP7/3602. figs 5-8, 18, 20. Provisocyntra ormistoni Feng n. sp.: 5, DP3/J007; 6, DP3/4631; 7, DP3/4636, holotype; 8, DP3/4540; 18, DP3/4638, magnification of fig. 8; 20, DP3/4635. figs 9-12, 19. Wuyia dongpanica Feng n. gen. \& sp.: 9, DP5/X011, holotype; 10, DP2/C008; 11, DP3/4609; 12, DP3/4412; 19, DP3/46091, magnification of fig. 11. figs 13, 17. Uberinterna virgispinosum Sashida \& Tonishi: 13, DP3/4252; 17, DP3/4253, magnification of fig. 13 (F, first medullary shell; S, second medullary shell; T, third medullary shell; IS, inner spicule). figs 14-16. Hegleria mammilla (Sheng \& Wang): 14, DP3/4819; 15, DP4/3429; 16, DP3/4744. Scale bar is $10 \mu \mathrm{m}$ in figs $12,18,19 ; 20 \mu \mathrm{m}$ in fig. 17; $50 \mu \mathrm{m}$ in figs $1,3,4,6-11,13-16,20 ; 100 \mu \mathrm{m}$ in figs $2,5$. 


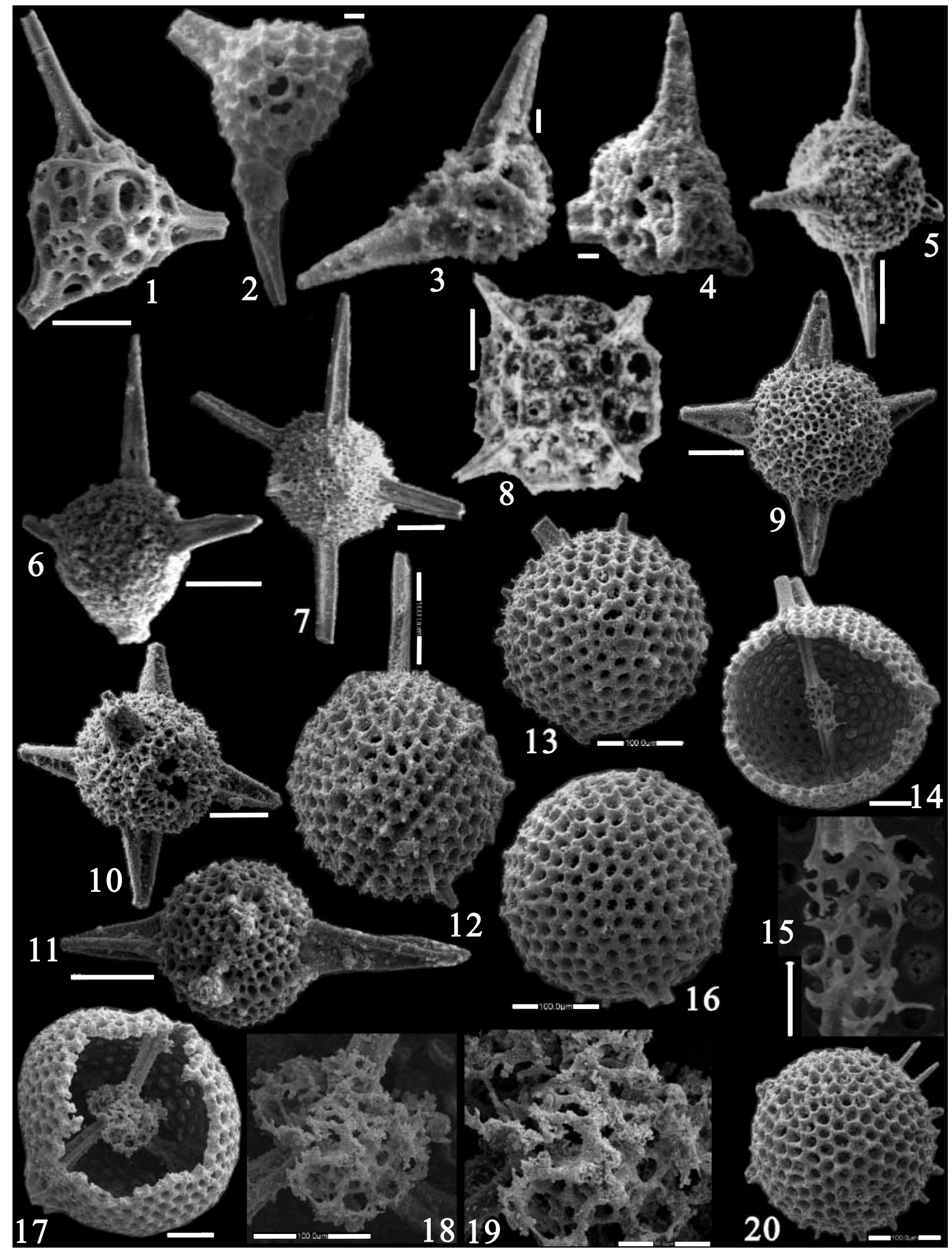


Latest Permian radiolaria, China

Wuyia dongpanica Feng n. gen. \& sp. (Pl. 5, figs 9-12, 19)

Derivation of name. According to the occurrence in the Dongpan section.

Diagnosis. A representative of Wuyia lacking a main spine.

Holotype. Plate 5 (fig. 9), sample DP3/4630 from the Dalong Formation of the Dongpan section, Fusui County, southern Guangxi, depositional number X0301-45.

Material. Eight specimens were recovered, of which six were examined by SEM.

Description. Test spherical in outline, composed of three concentric shells and a small microsphere. Cortical shell is thin, with numerous very short three- to four-bladed spines; pores oval, small. The cortical and first inner shells are connected by numerous beams; and the distance between both shells is about half the radius of the test. The beam varies in thickness, the middle part is thin and circular in cross-section, and the parts near both shells are wider, three- to four-bladed. At least four three-bladed beams link other inner shells and microsphere.

Dimensions $(\boldsymbol{\mu m})$. Based on six specimens: diameter of cortical shell 167-189; diameter of first inner shell 91-99; diameter of second inner shell 32; diameter of microsphere 8 .

Distribution. Late Changhsingian, South China.

Remarks. This new species differs from Middle Permian Wuyia endocarpa (Nazarov \& Ormiston, 1993) in lacking a main spine.

Genus Hegleria Nazarov \& Ormiston, 1985

Type species. Hegleria mammifera Nazarov \& Ormiston, 1985.

Hegleria mammilla (Sheng \& Wang, 1985)

(P1. 5, figs 14-16)

1985 Phaenicosphaera mammilla Sheng \& Wang: 179-180, pl. 3, figs $1-8$.

1985 Hegleria mammifera Nazarov \& Ormiston: 22, pl. 6, figs 3-5.

1987 Phaenicosphaera mammilla Sheng \& Wang; Kozur \& Krahl: 365-366, fig. 7a.

1990 Hegleria mammifera Nazarov \& Ormiston; Noble \& Renne: 387, pl. 1, figs 9, 10.

1992 Hegleria mammilla (Sheng \& Wang); Blome \& Reed: 369, pl. 11, figs 10, 12, 13.

1993a Phaenicosphaera mammilla Sheng \& Wang; Wang: 449, pl. 2, figs 1-6. 1993b Phaenicosphaera mammilla Sheng \& Wang; Wang: 466, pl. 2, figs 13-16.

1994 Hegleria mammilla (Sheng \& Wang); Wang \& Li: 209-210, pl. 1, figs 22, 23.

1997 Hegleria mammilla (Sheng \& Wang); Wang \& Fan: 66, pl. 1 , figs $1-3$.

1998 Hegleria mammilla (Sheng \& Wang); Feng et al.: 240, figs $3 \mathrm{f}-3 \mathrm{~h}, 3 \mathrm{k}$.

2000b Hegleria mammilla (Sheng \& Wang); Sashida et al.: 252, pl. 3, figs 1-4, 6 .

2002 Hegleria mammilla (Sheng \& Wang); Feng \& Gu: 801, figs 4.1-4.3.

Material. The species is abundant in our material. Twenty specimens were examined by SEM.

Distribution. Middle and Late Permian; South and Southwest China, North America, Thailand and Sicily.

Remarks. Sheng \& Wang (1985) and Nazarov \& Ormiston (1985) described this species as Phaenicosphaera mammilla and Hegleria mammifera, respectively. Kozur \& Krahl (1987) considered that Hegleria mammifera should be a junior synonym of Phaenicosphaera mammilla. Blome \& Reed (1992) suggested Hegleria mammilla (Sheng \& Wang) was used instead of Hegleria mammifera and Phaenicosphaera mammilla according to the law of priority in the nomenclature and because the genus Phaenicosphaera is a modern radiolarian form. Sheng \& Wang (1985) did not illustrate the interior structure of this species. The holotype of Hegleria mammifera (Nazarov \& Ormiston, 1985, pl. 6, fig. 3) is different from the specimen the authors illustrated for the inner structure (pl. 6, fig. 5, possibly belonging to Grandetortura Sashida \& Tonishi, 1991). De Wever et al. (2001) suggested that Hegleria possibly belongs to the Family Pseudolitheliidae Kozur \& Möstler, 1989. Therefore, the higher taxonomy of the genus remains a puzzle.

On the basis of many investigations, this genus is characterized by having a thick spherical cortical shell with numerous conical mammae on the surface and two to three medullary shells; each mamma has numerous small pores framed by thick bars; first medullary shell connected to the cortical shell by multiple rays. Therefore, it is believed that it should belong to the Family Entactiniidae Riedel, 1967.

Genus Uberinterna Sashida \& Tonishi, 1988

Type species. Uberinterna virgispinosum Sashida \& Tonishi, 1988.

Uberinterna virgispinosum Sashida \& Tonishi, 1988

(Pl. 5, figs 13, 17)

1988 Uberinterna virgispinosum Sashida \& Tonishi: 531-532, figs 8.7-12.

Explanation of Plate 6.

fig. 1. Genus \& species indet., DP4/3389. figs 2-4. Triaenosphaera sp. 3: 2, DP3/4210; 3, DP3/4315; 4, DP3/4620. figs 5-7. Spongentactinia? sp.: 5, DP5/2205; 6, DP3/4627; 7, DP4/3235. fig. 8. Polyentactinia sp., DP5/2594. figs 9-11. Wuyia permica (Sashida \& Tonishi): 9, DP5/1605; 10, DP2A029; 11, DP5/2327. figs 12-20. Kashiwara magna Sashida \& Tonishii: 12, DP4/O038; 13, DP5/X014; 14, DP2/C020; 15, DP2/C021, magnification of fig. 14; 16, DP2/A079; 17, DP4/R009; 18, DP4/R010, magnification of fig. 17; 19, DP4/R011, magnification of fig. 17; 20, DP5/Y017. Scale bar is $10 \mu \mathrm{m}$ in figs $2-4 ; 20 \mu \mathrm{m}$ in fig. $15 ; 50 \mu \mathrm{m}$ in figs $1,5-11,14,17,19 ; 100 \mu \mathrm{m}$ in figs $12,13,16,18,20$ ). 
Material. The species is rare in our material. Five specimens were examined by SEM.

Distribution. Late Permian, Japan and South China.

Remarks. This species is similar to Hegleria mammilla (Sheng \& Wang) in outline and structure of cortical shell, but differs from it in having six three-bladed beams between the cortical shell and the external medullary shell and in having more than three medullary shells.

\section{Family Spongentactiniidae Nazarov, 1975}

Type genus. Spongentactinia Nazarov, 1975.

Diagnosis. Spongy Entactinaria with an initial spicule of six or more spines, usually with a medullary and a cortical shell (De Wever et al., 2001).

Range. Formerly, the family was recovered only from the Devonian and Carboniferous (De Wever et al., 2001). This is the first report from the Permian.

Genus Provisocyntra Nazarov \& Ormiston, 1987

Type species. Provisocyntra cassicula Nazarov \& Ormiston, 1987.

Provisocyntra densa Feng n. sp.

(P1. 5, figs 1-4)

Derivation of name. densus $-u m-a($ Latin, adj. $)=$ dense.

Diagnosis. A very large Provisocyntra composed of dense concentric shells and lacking long radial spines.

Holotype. Plate 5 (fig. 1), sample DP3/4630 from the Dalong Formation of the Dongpan section, Fusui County, southern Guangxi, depositional number X0301-43.

Material. Nine specimens were recovered, of which six were examined by SEM.

Description. Test is very large, spherical, composed of about 20 concentric shells. Distance between two adjacent shells is very short. The shell is meshed by rod-like bar and connected by beams. Pores are small and irregular. Spines are few and very short. The inner structure of the medullary shell is unknown.

Dimensions $(\boldsymbol{\mu m})$. Based on five specimens: diameter of test 980-1320.

Distribution. Late Changhsingian, South China.

Remarks. This new species differs from the other species of Provisocyntra by its large test, dense concentric layers and a poorly developed spine.

Provisocyntra ormistoni Feng n. sp.

(Pl. 5, figs 5-8, 18, 20)
Derivation of name. This species is named for Dr Allen R. Ormiston, in honour of his studies on Palaeozoic Radiolaria.

Diagnosis. Medium-sized Provisocyntra with few, short, rod-like spines and composed of dense concentric shells.

Holotype. Plate 5 (fig. 7), sample DP3/4636 from the Dalong Formation of the Dongpan section, Fusui County, southern Guangxi, depositional number X0301-44.

Material. Eleven specimens were recovered, of which five were examined by SEM.

Description. Test medium, spherical. Outer shell with few, short, rod-like spines. Pores small, variable and irregular in form. Inner shells are covered by thin rods and connected by straight beams. Each beam is slightly wider rods.

Dimensions $(\mu \mathrm{m})$. Based on five specimens: diameter of shell 480-940.

Distribution. Late Changhsingian Permian, South China.

Remarks. This new species is similar in outline and structure to Provisocyntra cassicula Nazarov \& Ormiston from the Early Carboniferous, but differs from the latter in having few, short outer spines.

\section{Genus Spongentactinia Nazarov, 1975}

Type species. Spongentactinia fungosa Nazarov, 1975.

Spongentactinia? sp.

(P1. 6, figs 5-7)

Material. Four specimens were recovered, of which three were examined by SEM.

Description. Test is small, spherical, with six main spines. Outer shell is spongy, with very small, oval pores. The main spines are uniform; they are three-bladed and gradually decrease in width distally.

Distribution. Late Changhsingian; South China.

Remarks. The specimens reported herein are assigned tentatively to the genus Spongentactinia Nazarov because their inner structure is unknown.

Family Polyentactiniidae Nazarov, 1975

Type genus. Polyentactinia Foreman, 1963.

Diagnosis. Entactinaria having a spicule with eight bar-centred spines and usually a single cortical shell with polygonal surface. With or without pylome (De Wever et al., 2001).

Distribution. Devonian or older to Late Cretaceous. 
Latest Permian radiolaria, China

Genus Polyentactinia Foreman, 1963

Type species. Polyentactinia craticulata Foreman, 1963.

Polyentactinia $\mathrm{sp}$.

(Pl. 6, fig. 8)

Material. Only a single specimen was found in this study.

Description. Test is a single cortical shell. The shell is subdivided into eight trapeziform and two square areas. Each area has four oval pores. Four main spines are three-bladed, short and medium in thickness.

Distribution. Late Changhsingian; South China.

Remarks. According to its characters, the specimen illustrated herein can be placed in the genus Polyentactinia Foreman, 1963.

Genus and species indeterminate

(Pl. 6, fig. 1)

Material. Only one specimen, illustrated.

Description. Test subspherical, with three co-planar spines. Cortical shell with thin, smooth bars forming subcircular to oval pores which are unequal in size. Spines are thin, three-bladed and gradually decrease in width distally. Inner shell is similar to the cortical shell in structure and composed of some thin bars.

Distribution. Late Changhsingian, South China.

Remarks. This indeterminate species resembles genus Cryptostephanidium Dumitrica (1978) in its shape of the cortical shell and number of spines but differs from it in having a latticed medullary shell.

\section{DISCUSSION}

Many studies on the mass extinction of Permian radiolarians indicated that the Changhsingian was a main extinction interval of the Permian radiolarian fauna and that this event was a gradual process (Kakuwa, 1996; Vishnevskaya, 1997; Kuwahara \& Yao, 1998). Our detailed investigation in the Dongpan Section, South China, however, shows that three orders of Radiolaria - Entactinaria, Spumellaria and Latentifistularia diversified rapidly during the Late Changhsingian, followed by rapid extinction at the end of the Changhsingian. Similar conclusions were reached by Kozur (1998) and Feng et al. (2000).

In the Dongpan Section, the highest diversity occurred in an interval between $267 \mathrm{~cm}$ (line A) and $979 \mathrm{~cm}$ (line B) below the Permian-Triassic Boundary (PTB) (Fig. 2), with 138 species belonging to the Orders Albaillellaria, Entactinaria, Spumellaria and Latentifistularia. Thirty-four species of the Order Entactinaria, as reported in this paper, were also found in the interval between lines A and B and 26 disappeared at line A (Fig. 2). From line A to the PTB, the radiolarian fauna decreased quickly in both diversity and abundance. Only eight of the 34 species extend through line A. The lithology of the section changes from bedded siliceous rocks to siliceous mudstones across line A, which indicates that productivity of the radiolarian fauna decreased quickly. Additionally, important changes in test structure took place in proximity to line A: most of the species with developed external spines disappeared, whereas most of the species that survived lack an external spine, or have undeveloped external spines. The external spines of some other species, such as Trilonche crassispinosa and Hegleria mammilla, became thinner and shorter across the line. Therefore, line A demarks an important event for the radiolarian fauna in this area.

Kozur (1993) erected four radiolarian ecological zones: (1) 0-50 m water depth, consisting almost exclusively of Copicyntrinae; (2) 50-200 $\mathrm{m}$ water depth, dominated by Entactinaria, accompanied by Copicyntrinae; (3) 200-500 m water depth, dominated by Entactinaria, accompanied by Copicyntrinae and Albaillellacea; (4) below $500 \mathrm{~m}$ depth, characterized by Albaillellacea, accompanied by Entactinaria, Ruzhencevispongacea and Phaenicosphaera. At the line A, the rapid decrease of the radiolarian fauna was not as a consequence of palaeoecological factors. Albaillellidae, Latentifistularia, Entactinaria and copicyntrids had similar extinction rates near line A. No new taxa occurred in the interval between lines A and the PTB. Globally, the rapid extinction of the radiolarian fauna at the end of the Changhsingian has been recorded in other sections in South China and Japan (Feng et al., 1998; Shang et al., 2001; Gu \& Feng, 2002; Xia et al., 2004).

In the Dongpan Section, line A also represents the upper limits of the Neoalbaillella optima Assemblage Zone and Albaillella triangularis Abundance Zone. Investigations on conodonts and radiolarians in the Guji-hachiman section indicates that the upper limit of these two zones corresponds to the upper limit of the Clarkina meishanensis zhangi Interval Zone (Yao et al., 2001). Taxa from the Clarkina meishanensis zhangi Interval Zone were recovered from Bed 24e in the Meishan Section D, Changxing, China (Mei et al., 1998). Therefore, the upper limit of the Permian bedded chert and line A, as indicated by rapid disappearance of the Changhsingian radiolarians in the Dongpan Section, corresponds to the upper limit of the limestone of Bed 24e and the extinction event as marked by the disappearance of benthics in the Meishan Section D, such as fusulinid and coral reef. The reasons for these changes are still not well understood.

\section{ACKNOWLEDGEMENTS}

This paper is the result of the Geoturn Group. The paper has been supported by NSFC (Project No. 40232025). The authors wish to express sincere thanks to Drs P. Dumitrica, H. Kozur and F. John Gregory for reviewing the manuscript of this paper.

\section{Manuscript received 22 November 2004 Manuscript accepted 15 January 2006}

\section{REFERENCES}

Afanasieva, M.S. 2000. Atlas of Paleozoic Radiolaria of the Russian Platform. Scientific World, Moscow, 480 pp.

Aitchison, J.C. 1993. Albaillellaria from the New England Orogen, Eastern NSW, Australia. Marine Micropaleontology, 21: 353-367.

Blome, C.D. \& Reed, K.M. 1992. Permian and early (?) Triassic radiolarian faunas from the Grindstone terrane, central Oregon. Journal of Paleontology, 66 (3): 351-383. 
Braun, A. 1990. Radiolarien aus dem Unter-Karbon Deutschlands. Courier Forschungsinstitut Senckenberg, 133: 1-177.

Bureau of Geology and Mineral Resources of Guangxi Zhuang Autonomous Region (BGMRGAR) 2001. 1:50,000 Liuqiao geologic map and explanatory notes. [in Chinese].

De Wever, P., Dumitrica, P., Caulet, J.P., Nigrini, C. \& Caridroit, M. 2001. Radiolarians in the sedimentary record. Gordon and Breach Science Publishers, Singapore, 533 pp.

Deflandre, G. 1973. Observations et remarques sur les Radiolaries Sphaerellaries du Paléozoïque, à propos dune nouvelle espèce viséenne, du genre Foremaniella Defl., parfait intermédiaire entre les périaxoplastidiés et les Pylentonémidés. Comptes Rendus des Seances de lAcadémie des Science (Paris), 276: 147-1151.

Dumitrica, P. 1978. Family Eptingiidae n. fam., extinct Nasselaria (Radiolaria) with sagittal ring. Dari de seama ale sedintelor, Institul de Geologie si Geofizica, Bucharest, 64: 27-38.

Feng, Q.L. \& Gu, S.Z. 2002. Uppermost Changhsingian (Permian) radiolarian fauna from southern Guizhou, southwestern China. Journal of Paleontology, 76 (5): 797-809.

Feng, Q.L., Fang, N.Q., Zhang, Z.F. \& Huang, J.H. 1998. Uppermost Permian Radiolaria from southwestern China. Journal of China University of Geosciences, 9 (3): 238-245.

Feng, Q.L., Yang, F.Q., Zhang, Z.F., Zhang, N., Gao, Y.Q. \& Wang, Z.P. 2000. Radiolarian evolution during the Permian and Triassic transition in South and Southwest China. In: Yin, H., Dickins, J.H., Shi, G.R. \& Tong, J. (Eds), Permian-Triassic Evolution of Tethys and Western Circum-Pacific. Elsevier, Amsterdam, 309-326.

Foreman, H.P. 1963. Upper Devonian Radiolaria from the Huron Member of the Ohio Shale. Micropaleontology, 9: 267-304.

Gourmelon, F. 1986. Étude des radiolaires du nodule phosphate du Carbonifere in ferieur de Bareilles, Hautes -Pyrenees, France. Geobios, 19 (2): 179-197.

Gourmelon, F. 1987. Les radiolaires tournaisiens des nodules phosphatés de la Montagne Noire et des Pyrénées Centrales. Biostratigraphie du Paléozöique, 6: 1-172.

Gu, S.Z. \& Feng, Q.L. 2002. Uppermost Permian Radiolarian Biostratigraphy of Southern Guizhou, Southwest China. Journal of China University of Geosciences, 13 (1): 44-47.

He, W.H., Feng, Q.L., Gu, S.Z. \& Jin, Y.X. 2005. Changhsingian (Upper Permian) radiolarian fauna from Meishan D Section, Changxing, Zhejiang in China and its paleoecological significance. Journal of Paleontology, 79 (2): 209-218.

Holdsworth, B.K. 1977. Paleozoic Radiolaria; stratigraphic distribution in Atlantic borderlands. In: Swain, F.M. (Ed.), Stratigraphic micropaleontology of Atlantic basin and borderlands. Elsevier, Amsterdam, 167-184.

Ishiga, H. 1990. Paleozoic radiolarians. In: Ichikawa, K., Mizutani, S., Hara, I., Hada, S. \& Yao, A. (Eds), Pre-Cretaceous terranes of Japan. Nippon Insatsu Shuppan Co. Ltd, Osaka, 285-295.

Kakuwa, K. 1996. Correlation between the bedded chert sequence of southwest Japan and $\delta^{13} \mathrm{C}$ excursion of carbonate sequence, and its significance to the Permian-Triassic mass extinction. The Island Arc, 5: $194-202$.

Kozur, H. 1993. Upper Permian radiolarians from the Sosio Valley Area, Western Sicily (Italy) and from the uppermost Lamar Limestone of West Texas. Jahrbuch der Geologischen Bundesanstalt Wien, 136 (1): 99-123.

Kozur, H. 1998. Some aspects of the Permian-Triassic boundary and of the possible causes for the biotic crisis around this boundary. Palaeogeography, Palaeoclimatology, Palaeoecology, 143: 227-272.

Kozur, H. \& Krahl, H. 1987. Erster Nachweis von Radiolarien im tethyalen Perm Europas. Neues Jahrbuch für Geologie und Paläontologie, Abhandlungen, 175: 357-372.

Kozur, H. \& Möstler, H. 1982. Entactinaria suborder nov., a new radiolarian suborder. Geologisch-Paläontologische Mitteilungen, Innsbruck, 11: 399-414.

Kozur, H. \& Möstler, H. 1989. Radiolarien und Schwammskleren aus dem Unterperm des Vorurals. Geologisch-Paläontologische Mitteilungen Innsbruck, Sonderband, 2: 147-275.

Kuwahara, K. \& Yao, A. 1998. Diversity of Late Permian radiolarian assemblages. News of Osaka Micropaleontologists, Special Volume, 11 33-46. [In Japanese with English abstract.].
Kuwahara, K. \& Yao, A. 2001. Late Permian radiolarian fauna change in bedded chert of the Mino Belt, Japan. News of Osaka Micropaleontologists, Special Volume, 12: 33-49. [In Japanese with English abstract.].

Mei, S.L., Zhang, K.X. \& Wardlaw, B.R. 1998. A refined succession of Changhsingian and Griesbachian neogondolellid conodonts from the Meishan section, candidate of the global stratotype section and point of the Permian-Triassic boundary. Palaeogeography, Palaeoclimatology, Palaeoecology, 143: 213-226.

Nazarov, B.B. 1975. Lower and Middle Paleozoic radiolarians of Kazakhstan (methods of investigation, systematics and stratigraphic significance). In: Raaben, M.E. (Ed.), Transactions of the Academy of Sciences of the USSR, Geological Institute. Izdatelstvo Nauka, Moscow, USSR, $203 \mathrm{pp}$.

Nazarov, B.B. \& Ormiston, A.R. 1983. Upper Devonian (Fransnian) radiolarian fauna from the Gogo Formation, western Australia. Micropaleontology, 29 (4): 454-466.

Nazarov, B.B. \& Ormiston, A.R. 1985. Radiolaria from the Late Paleozoic of the Southern Urals, USSR and West Texas, USA. Micropaleontology, 31 (1): 1-54.

Nazarov, B.B. \& Ormiston, A.R. 1987. A new Carboniferous radiolarian genus and its relation to the multishelled entactiniids. Micropaleontology, 33 (1): 66-73.

Nazarov, B.B. \& Ormiston, A.R. 1993. New biostratigraphically important Paleozoic Radiolaria of Eurasia and North America. In: Blueford, J.R. \& Murchey, B.L. (Eds), Radiolaria of giant and subgiant fields in Asia. Special Publication. Micropaleontology Press, New York, 22-60.

Noble, P. \& Renne, P. 1990. Paleoenvironmental and biostratigraphic significance of siliceous microfossils of the Permo-Triassic bedding section, eastern Klamath Mountains, California. Marine Micropaleontology, 15: 379-391.

Ormiston, A.R. \& Lane, H. 1976. A unique radiolarian fauna from the Sycamore Limestone (Mississippian) and its biostratigraphic significance. Palaeontographica, 154 ((4-6)): 158-180.

Riedel, W.R. 1967. Subclass Actinopoda. In: Harland, W.B. , et al. (Eds), Protozoa, the Fossil Record. Geological Society, London, 291-298.

Sashida, K. \& Tonishi, K. 1985. Permian radiolarians from the Kanto Mountains, central Japan - Some Upper Permian Spumellaria from Itsukaichi, western part of Tokyo Prefecture. Science Reports of the Institute of Geoscience, University of Tsukuba, B6: 1-19.

Sashida, K. \& Tonishi, K. 1988. Additional note on Upper Permian radiolarian fauna from Itsukaichi, western part of Tokyo Prefecture, Central Japan. Transactions and Proceedings of Palaeontological Society of Japan, New Series, 151: 532-542.

Sashida, K. \& Tonishi, K. 1991. An Upper Permian coiled radiolarian from Itsukaichi, central Japan. Micropaleontology, 37 (1): 86-94.

Sashida, K., Adachi, S., Igo, H., Koike, T. \& Ibrahim, B.A. 1995. Middle and Late Permian radiolarians from the Semanggol Formation, Northwest Peninsular Malaysia. Transactions and Proceedings of Palaeontological Society of Japan, New Series, 177: 43-58.

Sashida, K., Igo, H., Adachi, S., Ueno, K., Kajiwara, Y., Nakornsri, N. \& Sardsud, A. 2000a. Late Permian to Middle Triassic radiolarian faunas from northern Thailand. Journal of Paleontology, 74 (5): 789-811.

Sashida, K., Salyapongse, S. \& Nakornsri, N. 2000b. Latest Permian radiolarian fauna from Klaeng, eastern Thailand. Micropaleontology, 46 (3): 245-263.

Shang, Q.H., Caridroit, M. \& Wang, Y.J. 2001. Radiolarians from the Uppermost Permian Changhsingian of Southern Guangxi. Acta Micropalaeonotology Sinica, 18: 229-240. [In Chinese with English abstract].

Sheng, J.Z. \& Wang, Y.J. 1985. Fossil Radiolaria from Kufeng Formation at Longtan Nanjing. Acta Palaeontologica Sinica, 24: 171-180. [In Chinese with English abstract].

Vishnevskaya, V. 1997. Development of Paleozoic-Mesozoic Radiolaria in the Northwestern Pacific Rim. Marine Micropaleontology, 30: 79-95.

Wang, R.J. 1993a. Fossil Radiolaria from the Kufeng Formation of Chaohu, Anhui. Acta Palaeontologica Sinica, 32: 442-457. [In Chinese with English abstract]. 
Wang, R.J. 1993b. Fossil radiolarians from the Kufeng Formation, Hushan area, Nanjing. Acta Micropalaeontologica Sinica, 10: 459-468. [In Chinese with English abstract].

Wang, Y.J. 1991. On progress in the study of Paleozoic radiolarians in China. Acta Micropalaeontologica Sinica, 8: 237-251. [In Chinese with English abstract].

Wang, Y.J. \& Fan, Z.Y. 1997. Discovery of Permian radiolarians in ophiolite belt on northern side of Xar Moron River, Nei Monggol and its geological significance. Acta Palaeontologica Sinica, 36: 58-69. [In Chinese with English abstract].

Wang, Y.J. \& Li, J.X. 1994. Discovery of the Follicucullus bipartitus-F. charveti radiolarian assemblage zone and its geological significance. Acta Micropalaeontologica Sinica, 11 (2): 201-212.

Wang, Y.J., Cheng, Y.N. \& Yang, Q. 1994. Biostratigraphy and systematics of Permian radiolarians in China. Palaeoworld, 4: $172-202$.

Won, M.Z. 1983. Radiolarien aus dem Unterkarbon des Rheinischen Schiefergebirges (Deutschland). Palaeontographica Abt. A, 182 ((4-6): $116-175$.
Wu, H.R., Kuang, G.D., Xian, X.Y., Li, Y.J. \& Wang, Z.C. 1994. Primary research on the Late Paleozoic radiolarian silicalite from southern Guangxi and Paleo-Tethys. Chinese Science Bulletin, 39: 809-812. [In Chinese with English abstract].

Xia, W.C., Zhang, N., Wang, G.Q. \& Kakuwa, Y. 2004. Pelagic radiolarian and conodont biozonation in the Permo-Triassic boundary internal and correlation to the Meishan GSSP. Micropaleontology, 50 (1): 27-44.

Yao, A. \& Kuwahara, K. 1999. Middle-Late Permian Radiolarians from the Guangyuan-Shangsi Area, Sichuan Province, China. Journal of Geosciences, Osaka City University, 42 (5): 69-83.

Yao, A. \& Kuwahara, K. 2000. Permian and Triassic radiolarians from the southern Guizhou Province, China. Journal of Geosciences, Osaka City University, 43 (1): 1-19.

Yao, J.X., Yao, A. \& Kuwahara, K. 2001. Upper Permian biostratigraphic correlation between conodont and radiolarian zones in the Tamba-Mino Terrene, Southwest Japan. Journal of Geosciences, Osaka City University, 44 (5): 97-119. 